\title{
MOBILIDADE DIGITAL NO CURSO DE PEDAGOGIA: O QUE PENSAM OS DOCENTES SOBRE O CELULAR NA SALA DE AULA
}

\author{
Digital Mobility in the Pedagogy Course: What Do Teachers Think about Cell Phones in \\ the Classroom
}

Elzicléia Tavares dos Santos*

\begin{abstract}
Resumo: Este artigo objetiva contribuir com a discussão sobre as tecnologias móveis no Ensino Superior, em especial o celular conectado à Internet. O propósito da pesquisa foi compreender os sentidos que os professores do curso de Pedagogia constroem em relação ao uso do celular com conexão à Internet em sala de aula. Os princípios da pesquisa qualitativa, na perspectiva histórico-cultural, embasaram o estudo com respaldo em Vygotsky $(1995 ; 2001$; 2007) e Bakhtin (2003); também foram usados os estudos sobre celular e mobilidade física e informacional na educação, a partir de Lemos (2005; 2009; 2010), Lévy (2010), Silva (2013), Santaella (2007; 2013), Cordeiro e Bonilla (2015; 2017), entre outros. A entrevista foi o instrumento desencadeador do discurso junto aos docentes que optaram por participar da pesquisa. Os resultados evidenciaram que os docentes estão construindo seus sentidos e significados a partir do que conhecem e das vivências tecidas com as tecnologias móveis. $\mathrm{O}$ uso do celular para consumo de informações na rede, com o intuito de realizar pesquisas, é o mais destacado pelos entrevistados como um uso significativo e permitido. Os docentes veem o celular na sala de aula como algo incômodo, causador de dispersão e de falta de concentração. A mobilidade informacional e do pensamento do estudante, a partir do uso do celular, confronta-se com a necessidade do professor de ter esse estudante conectado à aula e não à rede. Tal realidade causa tensões e desafios de ser docente na cultura digital.
\end{abstract}

Palavras-chave: Tecnologias móveis. Docente. Cultura digital. Sentido e Significado.

Abstract: This article aims to contribute to the discussion about mobile technologies in Higher Education, especially the mobile phone connected to the Internet. The purpose of the research was to understand the meanings that teachers of the Pedagogy course build in relation to the use of mobile phones with Internet connection in the classroom. The principles of qualitative research, in the historical and cultural perspective, supported the development of the study, supported by Vygotsky (1995; 2001; 2007) and Bakhtin (2003); and studies about cell phones and physical and informational mobility in Lemos (2005; 2009; 2010); Lévy (2010), Silva (2013); Santaella (2007, 2013), Cordeiro and Bonilla (2015; 2017),among others. The interview was the instrument to get the discusses with the teachers that chose to participate of the research. The results showed that teachers are building their senses and meanings based on what they know and the experiences ocurred with mobile technologies. The use of mobile phones to consume information on the network, in order to conduct research, is the most highlighted by respondents as a significant use. Teachers see the cell phone in the classroom as a nuisance, causing dispersion and lack of concentration. The informational mobility and the student's thinking, from the use of the mobile phone with internet connection in the classroom,

\footnotetext{
* Doutora em Educação pelo Programa de Pós-Graduação em Educação da Universidade Federal de Juiz de Fora, MG. Mestre em Educação pela PUC Minas Gerais. Professora adjunta da Universidade do Estado da Bahia Departamento de Educação, Campus X, Teixeira de Freitas, BA. E-mail: cleiatavares@yahoo.com.br.
} 
is confronted with the teacher's need to have this student connected to the classroom, not to the mobile phone. This reality causes tensions and challenges of being a teacher in the digital culture.

Keywords: Mobile Technologies. Teacher. Digital culture. Sense and Meaning.

\title{
1 Iniciando a conexão
}

\begin{abstract}
Os nômades virtuais buscam novos territórios, os territórios informacionais. Eles passam de ponto a ponto em busca não de água, caça ou lugares sagrados, mas lugares de conexão. Não precisam carregar seus pertences nas costas já que tudo o que precisam está virtualmente na rede.
\end{abstract}

André Lemos (2009)

É instigante a ideia expressa por Lemos (2009), que, há dez anos, retratava com muita ênfase e significação a relação dos sujeitos na contemporaneidade com os dispositivos móveis, sobretudo os smartphones/celulares com conexão à Internet ${ }^{1}$. Recorro a ela, em primeiro lugar, pela plurissignificação que enfeixa sua riqueza metafórica; segundo, é inegável a multiplicidade de redes que enreda os sujeitos e, ao mesmo tempo, provoca-os a mirá-las com um olhar crítico sobre seus macro e micro movimentos infindáveis, pois já não se sabe quais dimensões do ser humano ou de suas interfaces não estão afetas pelos intercâmbios de ideias por meio de redes digitais, ou que ainda estejam alijadas do ciberespaço neste século em curso. Problematizar essa temática será o tom da discussão que aqui se inicia.

Em 2014, uma empresa automobilística chamou a atenção de todos ao fazer um comercial no qual um rapaz aparece despido, ao se dar conta de que saiu de casa sem seu aparelho celular. O comercial brincava com a sensação do sujeito de se sentir nu, porque se esqueceu do celular em casa. É claro que a intenção da empresa era justamente chamar a atenção, levar ao convencimento de que o carro novo do comercial teria conexão à Internet e esse problema estaria resolvido. Além disso, também aborda o sentimento excessivo de dependência dos sujeitos com as tecnologias móveis. Como salienta Santaella (2007, p. 231232), "os celulares computadorizados são menores que os mouses dos desktops, movem-se por todos os lados, companheiros inseparáveis de seus donos, que os levam até para o banheiro". Esses aparelhos tornaram-se criaturas sensíveis, quase vivas.

Os dados da Anatel indicam que o Brasil terminou outubro de 2018 com 233,3 milhões de celulares e densidade de 111,34 cel./100 habitantes ${ }^{2}$. A Pesquisa Nacional por Amostra de Domicílios (PNAD), realizada em 2017, aponta que o equipamento mais usado para acessar a internet em nosso país é o celular, com 97,0\%; em segundo lugar, aparece o microcomputador, com 56,\%; a televisão surge em $3^{\circ}$ lugar, com 16,3\%; e em $4^{\circ}$ lugar, com 14,3\%, estão os Tablets. Os dados mostram um crescimento em relação ao ano de 2016, sobretudo do acesso pelo celular e da televisão. O interesse, neste estudo, volta-se às informações sobre o acesso realizado pelo celular.

\footnotetext{
${ }^{1}$ No meio digital, os smartphones são a evolução dos celulares comuns e possuem tecnologias que vão muito além de ligações e mensagens de texto. Possuem um sistema operacional complexo - Android, iOS ou Windows — com a possibilidade de instalar aplicativos e telas sensíveis ao toque; ou seja, são minicomputadores de bolso.

2 Dados coletados no site http://www.teleco.com.br/ncel.asp, <acesso em 18/12/2018>.
} 
Observa-se que a comunicação realizada através de dispositivos móveis está dando pistas de novas práticas sociais e comunicacionais ${ }^{3}$ $\mathrm{Na}$ cultura da mobilidade, a comunicação está cada vez menos confinada a lugares fixos e os novos modos de telecomunicação têm alterado a nossa concepção cotidiana do tempo e do espaço.

Desse modo, compreendo as tecnologias como produção do homem, portanto, provenientes das atividades humanas que vêm trazendo alterações na sociedade nas formas de organizar-se, de relacionar-se econômica, social e politicamente, de divertir-se, de comunicarse e, também, de ensinar e aprender, substancialmente pelos avanços tecnológicos. Como sintetizam Lemos e Lévy (2010, p. 30),

Essa transformação se deu na evolução da inteligência artificial e grande informática na década de 1950, no surgimento da microinformática na década de 70 , na consolidação do ciberespaço nos anos 1990 e na atual força das mídias móveis e locativas dos anos 2000. [grifos meus].

No momento, o crescimento das tecnologias móveis é visível ${ }^{4}$. Para facilitar a mobilidade, os dispositivos móveis geralmente possuem dimensões reduzidas, são leves e multifuncionais, permitindo a comunicação via textos, áudio, vídeo e com serviços como geolocalização. Nesse contexto, o telefone celular é o dispositivo de uso mais evidente entre as tecnologias móveis. Lemos (2005) define-o como "teletudo", pois, ao mesmo tempo em que é um telefone, pode ser também uma câmera fotográfica, televisão, cinema, meio de acesso a redes sociais, ferramenta para envio e recebimento de $e$-mails e SMS, tocador música etc.

Interessante é perceber que essa descrição das possibilidades do celular foi escrita em 2005. Já se passaram 14 anos e suas funcionalidades só aumentam. Desse modo, como poderíamos denominar o aparelho celular de 2019, uma vez que a cada mês é lançada uma nova versão de um aparelho com diversas configurações e maior capacidade de armazenamento? De certo que nem todos tinham acesso a um aparelho com todas essas funções descritas pelo autor em 2005 em nosso país. No entanto, o "teletudo" descreve muito bem o celular da atualidade 5 .

Santaella (2013) acredita que os celulares fascinam cada mais os usuários pelo fato de convergirem vídeos, jogos, músicas, fotos e, ao mesmo tempo, manterem uma comunicação ubíqua. "Não são mais dispositivos que permitem a comunicação oral, mas sim um sistema de comunicação multimodal, multimídia e portátil” (2013, p. 23).

\footnotetext{
${ }^{3}$ Um exemplo foi a campanha para presidente em nosso país no ano de 2018 , na qual os candidatos articularam a divulgação e propaganda eleitoral pelas redes sociais, em especial pelo uso do aplicativo WhatsApp, gerando denúncias de uso ilícito da plataforma com a propagação de Fake News, ou seja, notícias falsas sobre os candidatos. Para mais informações, ler https://brasil.elpais.com/especiais/2018/eleicoes-brasil/conversacoes-whatsapp/, <acesso em 30 de outubro de 2018>.

${ }^{4} \mathrm{Na}$ literatura, são considerados móveis os dispositivos portáteis com comunicação via tecnologia móvel sem fio, como telefone celular, tocadores de áudio (ipod, mp3 etc.), console de games, computadores portáteis, como notebook, netbook, tablet, além de dispositivos como e-book etc. (SILVA; COUTO, 2013, p. 125).

${ }^{5}$ Considero o André Lemos uma das referências intelectuais brasileiras sobre a temática das tecnologias digitais móveis. Parece estranho recorrer a um texto datado de 2005 para abordar sobre celular em 2019, no entanto, ao ler o texto do autor, tenho a impressão de que são previsões do que iria ocorrer na maioria das cidades brasileiras, sobretudo as cidades do interior; ou então, de que o autor descreve cidades de países desenvolvidos que já possuíam o desenvolvimento tecnológico com as redes sem fio em 2005.
} 
Para Lemos (2010), o desenvolvimento da computação móvel e das novas tecnologias sem fio têm início no começo do século XXI, com a passagem do "ponto de presença" ao "ambiente generalizado por conexão", envolvendo o usuário em plena mobilidade.

Desse modo, a mobilidade digital permite tanto o acesso instantâneo à comunicação como a possibilidade de responder, opinar, reagir às mensagens e às informações recebidas ou acessadas. Como destacam Cordeiro e Bonilla (2015, p. 2): "Os usos são diversos e neles estão presentes ressignificações, re-desterritorializações e subjetivações”. Entretanto, no interior da sala de aula, a mobilidade digital por meio dos celulares conectados pode ter sentidos e significados diferentes para estudantes e professores.

Indagações a respeito de como esse processo se dá nas escolas e nas universidades me levaram a investigar as potencialidades e os limites do aparelho celular com conexão à Internet como um auxiliar na construção do conhecimento no curso de Pedagogia em uma universidade pública no interior da Bahia. A pesquisa foi desenvolvida em 2015 e 2016, no programa de Iniciação Científica da UNEB, e contou com bolsistas de Iniciação Científica em três subprojetos interconectados ${ }^{6}$ : dois subprojetos foram voltados para os estudantes do curso de Pedagogia e Letras-Português e um subprojeto foi voltado para os professores do colegiado de Pedagogia. Nesse artigo, trago um recorte da pesquisa, no qual discuto os enunciados dos docentes do curso de Pedagogia sobre o celular na sala de aula.

A pesquisa teve como ancoragem os princípios basilares da metodologia qualitativa na perspectiva histórico-cultural, com respaldo em Vygotsky (1995; 2001; 2007) e Bakhtin (2003); e da tecnologia digital móvel, em Lemos (2005; 2009; 2010), Lévy (2010), Silva (2013), Santaella (2007; 2013), Cordeiro e Bonilla (2015; 2017), entre outros.

O trabalho investigativo teve como corpus docentes do curso de Pedagogia do Departamento de Educação, Campus X, entre 2015 e 2016. No semestre pesquisado, havia 21 professores atuando no curso de Pedagogia, 01 (um) professor afastado para doutorado, 01 (um) professor afastado para pós-doutorado e 07 (sete) professores de outros cursos e que estavam ministrando algum componente curricular no curso de Pedagogia no momento da pesquisa. Foram agendadas entrevistas com 05 (cinco) professores que se dispuseram a participar? ${ }^{7}$

As entrevistas semiestruturadas foram realizadas de forma individual e aconteceram em dias e horários determinados de acordo com a disponibilidade de cada professor nas dependências do Departamento de Educação Campus X. As questões, no primeiro momento, tinham como objetivo conhecer a relação do docente com as tecnologias digitais de um modo geral e quais tecnologias eles costumavam utilizar em sala de aula. Em seguida, foi abordada a relação com as tecnologias digitais móveis e quais as opiniões sobre uso do celular na sala de aula no ensino superior. Outra questão foi saber se o professor concebia o aparelho celular como um instrumento que contribui para o processo de aprendizagem do aluno do ensino superior.

As entrevistas foram gravadas com o aparelho celular e o material foi transcrito para a compreensão dos sentidos e significados dos enunciados dos sujeitos, na dimensão da análise temática, descobrindo os núcleos de significação e interpretando as falas dos docentes. No ato

\footnotetext{
6 O projeto de pesquisa "TECNOLOGIAS MÓVEIS NA CULTURA DIGITAL: mobilidade, conexão e aprendizagem nas licenciaturas" foi aprovado pelo Comitê de Ética da UNEB. N. do Parecer 1.226.042.

${ }^{7}$ A bolsista de Iniciação Científica Adayane de Souza Degobi, discente do curso de Pedagogia, foi a responsável pelas entrevistas. Como professora coordenadora da pesquisa, orientei todo o trabalho de campo, mas optei por não participar das entrevistas com os professores, para não influenciar as suas respostas, uma vez que sou professora da disciplina Tecnologias da Informação e Comunicação e faço parte do Colegiado. Assim, entrei em contato com o Colegiado e solicitei a colaboração dos professores com o trabalho da bolsista.
} 


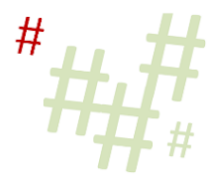

das entrevistas, pesquisador e pesquisados tornam-se parceiros de uma experiência dialógica, na qual os discursos do pesquisador e do pesquisado se cruzam e entrecruzam alimentando o diálogo.

\section{A perspectiva histórico-cultural no fazer pesquisa}

Os autores que fundamentaram os princípios basilares da metodologia qualitativa na perspectiva histórico-cultural neste trabalho, Vygotsky (1995; 2001; 2007) e Bakhtin (2003), defendem uma proposta dialógica de ciência que não apaga o sujeito; pelo contrário, a radicalidade teórica dos dois autores está justamente na defesa do ser humano não como coisa, mas como pessoa historicamente situada, como enfatiza Freitas (2002; 2003). Bakhtin (2003) propõe uma epistemologia em pesquisa nas Ciências Humanas, na qual pesquisador e pesquisado sejam sujeitos ativos e prenhes de perspectivas na produção de sentidos. Isso é de extrema importância nas pesquisas educacionais. Meu encontro é com o outro na pesquisa, e suas vozes repercutem sentidos diversos e visões diferentes de mundo que me lançam à sua compreensão. Nesse encontro com o outro, emerge a alteridade bakhtiniana. Diante disso, o ser se constitui e se transforma com o outro nas interações com as palavras e com os signos.

Vygostky (2007), no início do século XX, defendeu o materialismo como caminho histórico e metodológico que pode atender à especificidade do objeto psicológico, com as idiossincrasias e subjetividades próprias do ser humano. Em sua abordagem, o sujeito é concebido como parte de um contexto cultural dialético e histórico. O elemento-chave do seu método de investigação é decorrente da concepção de Engels de que, ao agir sobre a natureza, o indivíduo nela provoca mudanças e cria condições naturais para sua própria existência. $\mathrm{O}$ autor concebe como requisito básico do método dialético o fato de que estudar algo historicamente é estudá-lo em suas mudanças, no seu devir, compreendendo o método como "pré-requisito e produto, o instrumento e o resultado do estudo" (VYGOSTKY, 2007, p. 69).

Na compreensão dos usos do celular como ferramenta ${ }^{8}$ que auxilia o processo de ensinoaprendizagem, é necessário identificar os sentidos e os significados que os sujeitos envolvidos constroem em torno desse instrumento. Tais termos são compreendidos a partir de Bakhtin e Vygotsky, porque significado e sentido são constituídos pela mediação semiótica envolvendo a apropriação dos signos.

Bakhtin (2003) destaca que a relação com o sentido é sempre uma relação dialógica. Mesmo que considerado fora do diálogo, o significado está abstraído de modo deliberado e convencional, porque nele existe uma potência do sentido. Já o significado da palavra descrito em um dicionário, por exemplo, não tem a mesma vivacidade e o dinamismo do sentido, segundo Bakhtin. O significado é mais estável e consolidado, mas também sofre mudanças no deslocar de um contexto apreciativo para outro.

Vygotsky (2001) compreende o sentido como uma formação dinâmica, fluida, complexa, com zonas de estabilidade variada. E o significado é compreendido como "apenas uma dessas zonas de sentido", sendo uma zona uniforme, estabilizada e exata. Para Vygotsky (2001, p. 465), "o significado é apenas uma pedra no edifício do sentido", o que confere ao significado a ideia de algo mais estável.

Tanto em Bakhtin quanto em Vygotsky, o que se destaca é que não é o objeto em si que é apropriado, mas a significação desse objeto, ou seja, o signo é apropriado pelo sujeito em sua significação e nas relações que se estabelecem mediadas pela cultura. Nesse processo, estão

\footnotetext{
${ }^{8}$ Ferramenta, aqui, é compreendida a partir dos estudos de Vygotsky.
} 
envolvidos o contexto histórico de que os sujeitos fazem parte e o que eles estabelecem como significativo para se apropriarem.

Apesar de não ter discutido as possibilidades das tecnologias digitais móveis para o desenvolvimento do indivíduo, Leffa (2009), citando Vygotsky, traça a seguinte reflexão, aqui tomada no contexto de valorização das tecnologias digitais no desenvolvimento intelectual do indivíduo: "A inclusão de uma ferramenta no processo do comportamento [...] altera o curso das características individuais [...] de todos os processos mentais que entram na composição do ato instrumental, substituindo algumas funções por outras" (VYGOTSKY apud LEFFA, 2009, p. 136). Nas palavras de Vygotsky, escritas antes do surgimento das tecnologias digitais, é possível perceber sua ênfase às transformações passadas pelas condições externas e, nesse sentido, pelos instrumentos culturais que usados. Cabe salientar que, aqui, a palavra ferramenta e/ou instrumento está empregada para denominar o aparelho celular com conexão à Internet, a partir da ideia de instrumento em Vygotsky, e não em uma perspectiva de instrumentalização do ensino. Como pontua Leffa (2009, p. 136-137), "as ferramentas nos tornam mais fortes e ágeis não apenas fisicamente, mas também mentalmente". Ou melhor, "não é só o mundo que nos muda; nós também mudamos o mundo, aperfeiçoando e criando novas ferramentas".

Na sociedade contemporânea, amplia-se o número de instrumentos que atuam como mediadores no desenvolvimento do pensamento humano e, entre eles, volto-me para as tecnologias digitais, em especial, o aparelho celular conectado à Internet. A compreensão de Vygotsky de que a cultura engloba a multiplicidade da produção humana, em suas diversas atividades sociais, leva-me a pensar nas tecnologias digitais como instrumentos culturais criados pelo homem e que carregam uma materialidade e uma significação, os dois componentes que caracterizam uma produção humana na perspectiva vygotskiana.

\section{Mobilidade: breve aproximação conceitual}

$\mathrm{Na}$ atualidade, devido à convergência digital, a Internet pode ser acessada por diferentes dispositivos tecnológicos, que não mais precisam estar fixados em um determinado local, mas que podem ser transportados para qualquer lugar. Estas características proporcionam a todos uma mobilidade física e informacional, como destacam Lemos (2009; 2010), Silva (2013), Santaella (2013) e Cordeiro e Bonilla (2015; 2017).

Mobilidade e conexão tornaram-se palavras de extrema relevância nos debates sobre tecnologias móveis e, nesse sentido, busco apoio teórico nos autores que estudam as tecnologias móveis. Lemos (2005) define mobilidade "como o movimento do corpo entre espaços, entre localidades, entre espaços privados e públicos". Para esse autor, "Parece que as novas práticas do espaço urbano surgem com a interface entre mobilidade, espaço físico e ciberespaço" (LEMOS, 2005, p. 3). Ou seja, as pessoas querem mover-se e carregar consigo seus aparelhos eletrônicos para não ficarem desconectadas. Assim, mobilidade vai além de transportar um dispositivo de pequeno porte que dê acesso às informações em qualquer lugar; engloba também o acesso à rede por meio da conexão sem fio.

Nesse contexto, a mobilidade é visualizada como a principal característica das tecnologias móveis que se propagam mundialmente e, da mesma maneira, no mercado brasileiro. Exemplo disso é que, em nosso país, o número de celulares ultrapassou o número de telefones fixos. É comum o acesso à rede sem fio em aeroportos, shoppings, cafés, bares, hotéis, parques, igrejas, supermercados e universidades.

Lemos (2009) propõe pensarmos em três dimensões da mobilidade: o pensamento, a física e a informacional. As três estão relacionadas e exercem influência umas sobre as outras. 
Para o autor, a comunicação é "uma forma de 'mover' informação de um lugar para outro, produzindo sentido, subjetividade, espacialização" (LEMOS, 2009, p. 2). Portanto, na visão do autor, não se pode dissociar comunicação, mobilidade, espaço e lugar.

A mobilidade física é o movimento de pessoas, objetos e corpos marcado pelo início da modernidade e pelo desenvolvimento das cidades. Embora a era contemporânea veja a ampliação da compreensão espaço-temporal, na qual comunicação, mobilidade informacional e deslocamento de pessoas ao redor do mundo são correlatos e se ampliam, a cultura da mobilidade faz parte da evolução da cultura humana como um todo. A mobilidade não é novidade nem advém do contexto tecnológico, no entanto as tecnologias ressignificam esse conceito.

A mobilidade informacional é responsável pela circulação constante de informação na rede. Assim, à medida que são registrados os acontecimentos diários, os sujeitos interagem e conversam uns com os outros, alimentando a mobilidade informacional. Com as novas mídias móveis digitais, ampliam-se as possibilidades de consumir, produzir e distribuir informação, de modo que isso se exerça e ganhe força a partir da mobilidade física.

Sem dúvida, os dispositivos móveis, como smartphones, tablets, celulares, palms, laptops, potencializam a mobilidade. Lemos (2009) cita como exemplo o fato de que o simples ato de enviar um SMS, uma foto, postar algo em blog ou alimentar redes sociais com um telefone celular revela essa nova relação sinérgica entre as mobilidades, infactível com os meios de comunicação anteriores, com os quais era possível apenas o consumo em mobilidade (ouvir rádio no carro, ler um livro no avião ou revista e jornal no ônibus), sendo a capacidade produtiva rara e a de distribuição imediata muito difícil.

Por outro lado, a mobilidade de pensamento presente nas práticas diárias é dinamizada e ganha potência com a conexão, a rede, e o constante movimento físico por diversos espaços. Assim, o pensamento e a reflexão podem ser ativados a qualquer momento por meio da necessidade de comunicar, processar informações, produzir e organizar algum conteúdo e disponibilizar as produções em rede.

Cordeiro e Bonilla $(2015 ; 2017)$ trabalham com as três dimensões da mobilidade defendidas por Lemos, e destacam que uma tem influência sobre a outra e quem não tiver acesso à informação e à comunicação estará, de certa forma, condenado à imobilidade social, cultural, econômica. Assim, a mobilidade irá variar de acordo com o grupo social no qual o sujeito está inserido.

Para Silva (2013), a mobilidade tem diversas características: a tecnológica, que irá permitir o uso de um dispositivo em local diferente; do conteúdo, que diz respeito ao acesso ao conteúdo, ao lugar onde foi produzido; e para além do local da sua produção, a capacidade de distribuição, de compartilhamento e de acesso por um ou por muitas pessoas. Ou seja, "a mobilidade e a apropriação social e coletiva dos dispositivos móveis são também uma característica da cultura digital" (SILVA, 2013, p. 126).

Nesse debate, Santaella (2013) acrescenta que “à mobilidade física do cidadão cosmopolita foi acrescida a mobilidade virtual das redes. Ambas as mobilidades entrelaçaramse, interconectaram-se e tornaram-se mais agudas pelas ações de uma sobre a outra (2013, p. 21).

Lemos (2009) chama a atenção para o fato de que a mobilidade não é natural, nem neutra, mas, sim, revela formas de poder. Existem diferentes graus de mobilidade que mostram diferenças de poderes contemporâneos, como tipos de acesso a máquinas, redes, espaços físicos, culturais e linguísticos. Por isso, Lemos (2009, p. 29) defende que ela deva ser politizada: "Os 
que podem movimentar-se mais facilmente pelo ciberespaço são também os que têm maior autonomia para deslocamento físico e vice-versa". Daí a importância de as universidades e escolas permitirem o acesso às redes sem fio para uso dos dispositivos móveis.

Isso ocorre porque as possibilidades tecnológicas da cultura digital, na qual se consegue, por meio de dispositivos sem fio, comunicar-se e informar a qualquer tempo e de qualquer lugar, estão viabilizando muito além de informação e entretenimento:

\begin{abstract}
O conjunto de práticas vivenciais que a mobilidade nos coloca, a dinamização e potencialização do pensamento, do deslocamento e da troca de informação, mediados pelas tecnologias digitais móveis, proporcionam um desprendimento das amarras de um contexto imediato, das limitações de um espaço/tempo cronológicos, delimitados, e sugerem aos interagentes/praticantes serem produtores de dinâmicas mais fluidas e flexíveis, o que potencializa uma reterritorialização e significação de espaços onde podem ser criados "novos sentidos de lugar", através da produção de ambientes de postagens de textos, imagens, mensagens, onde se distribui informação e se participa, cocriando nesse novo espaço (CORDEIRO; BONILLA, 2015, p. 264).
\end{abstract}

Assim, as tecnologias móveis permitem o desprendimento do contexto imediato, das limitações de tempo e de espaço. Para Lemos (2008), tal realidade contribui para produzir e potencializar a reterritorialização. Sai-se de seu lugar e passa-se a habitar outro, criando novos sentidos de lugar e novos territórios.

O termo território, nos dicionários de língua portuguesa, corresponde a um espaço concreto que possui limites estabelecidos. É uma delimitação do espaço geográfico e político de um lugar. De certo que são diversos sentidos e significados para o termo território. Tendo em vista a discussão de mobilidade a partir de Lemos $(2005 ; 2008 ; 2009)$, trago sua concepção acerca do conceito de território:

\begin{abstract}
A noção de território é polissêmica e não deve ser entendida apenas pelo aspecto jurídico, como espaço físico delimitado. Definimos território através da ideia de controle sobre fronteiras, podendo essas serem físicas, sociais, simbólicas, culturais, subjetivas. Criar um território é controlar processos que se dão no interior dessas fronteiras. Desterritorializar é, por sua vez, se movimentar nessas fronteiras, criar linhas de fuga, ressignificar o inscrito e o instituído (LEMOS, 2008, p. 6).
\end{abstract}

É comum ser proferida a informação "aqui é meu território, minha área, meu domínio", quando o sujeito pretende destacar o espaço físico que conhece, vive, sobre o qual tem maior domínio e onde transita com facilidade e desenvoltura. É interessante a fala de Lemos (2008) de que a criação de um território é exercer controle dos processos que ocorrem no interior das fronteiras. Para o autor, "Todo espaço, físico ou simbólico, apropriado por forças políticas, econômicas, culturais ou subjetivas, se transforma em território" (LEMOS, 2008, p. 7). O sujeito que desterritorializa busca movimentar, criar linhas de fuga do instituído. E esse processo se amplia na cibercultura, por ser esta caracterizada como uma cultura da desterritorialização.

Ela nos coloca em meio a diversos problemas de fronteiras, agravando as crises de controle e de acesso, influindo em todas as demais formas de desterritorializações contemporâneas. A desterritorialização informacional afeta a política, a economia, o 
sujeito, os vínculos identitários, o corpo, a arte. A Internet é, efetivamente, máquina desterritorializante sob os aspectos político (acesso e ação além de fronteiras), econômico (circulação financeira mundial), cultural (consumo de bens simbólicos mundiais) e subjetivo (influência global na formação do sujeito) (LEMOS, 2008, p. 8).

Nesse contexto, surge a indagação: como fica a sala de aula, um território pensado para atenção e foco na fala do professor e no qual os estudantes estão com celulares que os convidam a desterritorializar o tempo todo? Para Lemos (2009), não existe desterritorialização sem nova reterritorialização. Ao sair da sua área, o indivíduo passa a habitar outro espaço, reterritorializando-o. Cordeiro e Bonilla, a partir de uma pesquisa realizada em escolas públicas na cidade de Salvador, pontuam que:

\begin{abstract}
A reterritorialização dos espaços/tempos escolares se intensifica à medida que o digital começa a fazer parte das práticas cotidianas dos interagentes/praticantes desse contexto, onde a dimensão das redes começa a se tornar cada vez mais presente. Os territórios que vão sendo construídos possibilitam relações mais horizontalizadas e plurais, tornando-se potenciais espaços de criação. Em consequência, os praticantes/interagentes estão reinventando o cotidiano das escolas e a si mesmos (CORDEIRO; BONILLA, 2015, p. 25).
\end{abstract}

Nessa pesquisa, as referidas autoras mostram os estudantes das escolas públicas por elas pesquisadas, que possuem um uso intenso das tecnologias móveis dentro e fora da sala de aula, e os processos desterritorializantes/reterritorializantes no cotidiano dessas escolas. Os resultados desse estudo contradizem muitas das falas de que os celulares com conexão atrapalham em sala de aula. É lógico que há tensões com as novas práticas, mas também há criação, construção e compartilhamento de conhecimento.

\title{
40 que pensam professores sobre o uso do celular no Ensino Superior: entre mobilidades, desconfiança e tolerância
}

O celular permite que o sujeito realize várias andanças sem sair de seu lugar físico. A pesquisa de Cordeiro e Bonilla (2015; 2017), com estudantes do Ensino Médio, evidenciou a fuga e a busca por outros espaços que lhes aparentavam serem mais agradáveis, dinâmicos e fluidos por meio dos celulares em sala de aula.

Como docente e pesquisadora nessa área, um uso muito frequente que percebo em minhas aulas é a busca por informação sobre o andamento das aulas. As turmas costumam ter grupos no WhatsApp por onde repassam os acontecimentos da aula para os demais. Alguns vêm, ou desistem de vir, para a aula a depender do que esteja acontecendo. Essa ação assemelhase ao que taxistas fazem ao entrar em contato via celular / WhatsApp com os colegas, para saber como está o tráfego em algum trecho e, assim, decidir por onde se deslocar.

Outro uso corriqueiro do celular em sala de aula pelos estudantes é para realizar fotografias e/ou filmagem das aulas, para terem esse registro e estudar em outros momentos.

Os aparelhos oferecem conectividade ininterruptamente, assim, ao mesmo tempo em que estão enviando torpedos, entrando nas redes sociais, estão tirando fotos do 
conteúdo que o professor passou no quadro, ou mesmo gravando a aula (CORDEIRO; BONILLA, 2015, p. 267).

Além de fotografar para si, eles também compartilham com os colegas as informações das aulas, criando uma memória imagética do vivido, assim como também usam o aplicativo de bloco de notas para registrar algo. Sobretudo, o comum é fotografar/gravar tudo: o caderno do colega, o livro, as anotações do professor no quadro, os slides do Power Point, a explicação do professor etc. Eu inclusive, como professora, realizo orientações de trabalhos científicos e autorizo os estudantes a fazerem gravação para ouvirem quando forem fazer as correções no texto em outro momento.

Também observo os estudantes fotografando livros e apostilas para não terem que gastar com cópias xerocopiadas. Fato é que os estudantes carregam consigo seus celulares o tempo todo, colados ao corpo como material escolar. É uma geração que está inserida em uma cultura digital e não abre mão desse aparelho em sala de aula. A partir de tais reflexões, questiona-se: Como os docentes veem essa relação dos estudantes com o celular em sala de aula?

Em diferentes intensidades e propósitos, os docentes entrevistados também se relacionam com o celular com acesso à Internet, participam de grupos no WhatsApp e de redes sociais. No entanto, se há quem não viva sem Internet, seja no celular, seja em outro dispositivo, há também aquele docente que usa o celular apenas para fazer ligações. Percebe-se como cada um é afetado, ou não, pelas possibilidades das tecnologias digitais na sociedade. São novos instrumentos que permitem novos hábitos de comunicar, estudar e aprender, porém nem todos os professores entrevistados estão envolvidos plenamente no movimento das tecnologias. Uns estão mais imersos; outros olham com criticidade os compartilhamentos em grupos de WhatsApp; e há aqueles que preferem usar o celular apenas como telefone mesmo.

Apesar de estarem conectados e fazerem parte da cultura digital, os docentes possuem opiniões diversas sobre uso do celular na sala de aula no Ensino Superior (informação verbal ${ }^{9}$ ):

Proibir eu não acho adequado, mas eu penso que a gente tem que criar uma forma de conscientizar as pessoas que usam de que não é bom, porque dispersa, e... é como se eu comparar o uso do aparelho celular é... em sala de aula com outras profissões, então você não iria gostar de estar fazendo uma cirurgia ou estar em uma viagem e o motorista do ônibus ficasse com uma mão no volante e a outra no aparelho. A mesma coisa seria na mesa de cirurgia ou em qualquer outra profissão, não é? É... seria estranho se o profissional desse atenção aos dois... às duas atividades, então a mesma coisa é sala de aula. Eu acho que é um pouco delicado, né? Eu acho que dispersa, eu não acho que seja positivo, eu olho com desconfiança. (Prof. A, grifo meu).

Eu não gosto, proibir eu não proíbo, é... o que eu não gosto e, é assim, não diria que é proibir, mas, assim, eu tenho um olhar, eu não admito a falar no telefone em sala de aula, alguém ligar e eu tô [sic] falando e a pessoa tá [sic] conversando, mas se a pessoa tá usando o WhatsApp e tá usando a Internet, para mim é indiferente isso aí. Agora, o que eu não gosto é estar falando ao telefone" — A ligação mesmo?, perguntei — É... a ligação. (Prof. B).

Não, proibir não. Aconteceram situações de eu chamar a atenção do aluno, em função de que o uso do celular não estava correspondendo a atividade em sala de aula. Nesse sentido, eu acho que, isso é... quando o estudante faz esse uso incorreto do aparelho, considero que não deve ser tolerado, porque tem uma atividade em curso, não é? Então, é preciso esse acompanhamento [...]. Se o estudante, ao invés de estar participando de alguma forma dessa atividade, está acessando esse celular, as redes

9 As informações verbais correspondem às entrevistas realizadas junto aos docentes. 

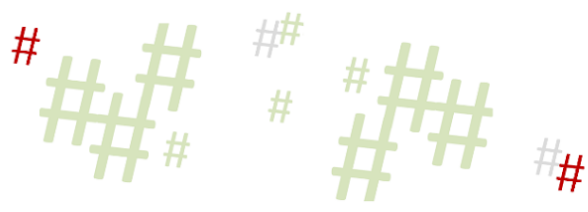

sociais, sem relação com a atividade, então eu acho que isso não deve ocorrer. Duas vezes em sala de aula, nesse semestre, eu precisei chamar a atenção do estudante por não estar acompanhando os trabalhos [...]; por outro lado, também tem momentos assim importantes de estar fazendo uma exposição, de estar participando de debate em sala de aula, e o estudante complementar informações, participar do debate, utilizando do assunto que tinha acessado na Internet naquele exato momento; eu considerei isso importante. (Prof. C, grifo meu).

Olha, eu não proíbo, mas os alunos já sabem que é melhor desligar o celular para a gente ter mais concentração na aula, então sou favorável que os alunos desliguem o celular. (Prof. D).

Os depoimentos fazem rememorar os estudos acerca do homem, em que são encontrados signos em toda parte, cujo significado os sujeitos se empenham em interpretar (BAKHTIN, 2003, p. 319). Percebo então que as falas dos docentes entrevistados estão prenhes de sentidos e significados para a questão do uso do celular na sala de aula no Ensino Superior, o que me leva a uma gama de interpretações, sendo reconhecida a impossibilidade de esgotar a discussão neste artigo. De suas falas, emergem termos que demarcam suas posições e seus olhares com relação à forma como denominam o celular: "desconfiança", "tolerância", "proibição", "dispersão", "atenção", "complemento das informações", "concentração", "instrumento".

Esses termos são empregados em muitas discussões calorosas sobre a presença dos celulares na sala de aula em qualquer disciplina no Ensino Superior. Os professores entrevistados não proíbem diretamente o uso do celular em sala de aula, mas há muitas restrições, preocupações e desconfianças do uso desse aparelho nesse contexto em suas narrativas. Por outro lado, há relato de atividades realizadas com sucesso em sala, graças à contribuição do celular.

Percebe-se que há um incômodo dos professores com os alunos que usam notebook e celular no decorrer das aulas, por acreditarem que os alunos não conseguem conciliar a atenção na aula e o uso desses aparelhos. Para eles, o instrumento em questão deixa os alunos dispersos, sem concentração nas aulas, muito mais envolvidos no acesso às redes sociais do que na finalidade de aprimorar seus conhecimentos. Uma voz que destoou das proibições e da intolerância foi a da Prof. ${ }^{a}$ E, que sinalizou várias contribuições do uso de celular na sala de aula e destacou que os professores desconhecem o uso pedagógico desse recurso. Em sua opinião, se eles soubessem, poderiam explorar mais o uso como apoio no desenvolvimento das aulas (informação verbal):

Quem sou eu para proibir o uso de celular, né? Mas ele é bem-vindo, em muitos momentos, quando o aluno está utilizando o celular é para pesquisa, mas infelizmente, na maioria das vezes, o aluno está usando mais para fins de recreação do que para fins acadêmicos. Então proibir não tem como você proibir, mas chamar atenção em alguns momentos que você não está necessitando do celular, isso de vez em quando tem que chamar atenção um pouquinho [...]. Se o professor soubesse como utilizar essa ferramenta em sala de aula, ela seria bastante proveitosa; é que, em alguns momentos que a gente precisa de Internet, de pesquisa de alguma coisa imediata, é importante demais, tanto para o aluno quanto para a dinâmica da aula; infelizmente é como vem sendo utilizado é que às vezes atrapalha até a dinâmica da aula" - Então você vê como uma espécie de instrumento?, questionou a pesquisadora - "Instrumento, isso mesmo! (Prof. ${ }^{a}$ E, grifos meus).

Em convergência aos depoimentos tomados, Silva e Couto (2013) salientam que utilizar os ambientes digitais nas práticas pedagógicas estimula a colaboração e é um apoio à aprendizagem dos alunos. Essas tecnologias promovem a construção colaborativa de 
conhecimento, assim como instigam o protagonismo dos alunos para avançar intelectualmente. Apesar disso, essas possibilidades ainda estão distantes do trabalho dos professores.

A mobilidade dos sujeitos em locais de difícil controle parece ser o principal motivo de preocupações. Aqui, é a mobilidade informacional e do pensamento, tal como definida por Lemos (2009), que causa desconfiança e preocupação. Fisicamente, o sujeito pode estar em sala de aula parado, mas frequentando diversos territórios informacionais ${ }^{10}$. Daí seu pensamento divaga e ele fica presente/ausente do movimento da sala de aula. Santaella (2007) contribui com o debate ao dizer que

O que alimenta as ambiguidades vigentes é o fato de que, no duplo nomadismo e na dupla mobilidade, as bordas entre os estados de presença e ausência que, nas sociedades tradicionais, eram nítidas tornaram-se borradas. Presença e ausência intercambiam-se, sobrepõem-se em um mesmo espaço, gerando vivência da ubiquidade: está lá, de onde me chamam, e estar aqui, onde sou chamado, ao mesmo tempo (SANTAELLA, 2007, p. 236).

De fato, os sujeitos, ao usarem os celulares, podem estar ausentes/presentes na sala de aula ou em qualquer lugar. Essa realidade desterritorializa o professor que, sem poder de controlar, opta por criar protocolos de usos ou até mesmo restrições. Sobre o tema, Lemos (2008, p. 9) esclarece que "as tecnologias de comunicação móveis são tidas como desterritorializantes, instituintes de processos nômades, justamente por criar deslocamentos de corpos e informação".

O autor destaca que as tecnologias móveis podem criar processos desterritorializantes, mas isso não ocorre pelo simples fato de se usar o artefato. Pelo contrário, essas tecnologias podem reforçar poderes constituídos e territorializados. Ou seja, o sujeito também pode estar usando a rede no ambiente de aula virtual e não sair desse espaço.

Cabe lembrar que os estudantes sempre levaram algo para sala de aula com vistas a se dispersar e divagar o seu pensamento. Se antes eles levavam revistas e livros escondidos nas bolsas ou entre os cadernos, hoje eles carregam revistas, vídeos, novelas, notícias, bate-papo, músicas etc. dentro do celular, para acesso a qualquer momento, com um simples toque dos dedos na tela. Cordeiro e Bonilla (2017, p. 2) compreendem que

Percebemos que os princípios que regiam uma maneira instituída de ser professor e fazer educação passam a ser tensionados diante da quebra de hierarquia decorrente das múltiplas fontes de acesso à informação e conhecimento, das relações espaçotemporais que são ressignificadas, quebrando a linearidade dos ritmos dentro da

\footnotetext{
${ }^{10}$ Lemos (2009) compreende por territórios informacionais as áreas de controle do fluxo informacional digital em uma zona de intersecção entre o ciberespaço e o espaço urbano. A partir dos dispositivos móveis e das redes sem fio, temos o acesso e o controle informacional. O território informacional não é o ciberespaço, mas o espaço movente, híbrido, formado pela relação entre o espaço eletrônico e o espaço físico. Por exemplo, o lugar de acesso sem fio em um parque por redes wi-fi é um território informacional, distinto do espaço físico parque e do espaço eletrônico Internet. Ao acessar a Internet por essa rede wi-fi, o usuário está em um território informacional imbricado no território físico (e político, cultural, imaginário etc.) do parque, bem como no espaço das redes telemáticas.
} 
escola e das demandas provenientes do mundo do trabalho e do mundo da vida de uma geração conectada.

$\mathrm{Na}$ rede informacional aqui envolvida, misturam-se vários saberes e formas muito diversas de aprender, enquanto o sistema educativo ainda se encontra todo organizado em torno da escola e do livro. O que se vive hoje, segundo Martín-Barbero (2006), é uma transformação nos modos de circulação do saber, que, disperso e fragmentado, circula fora dos lugares sagrados que antes o detinham e das figuras sociais que o geriam. Portanto, a escola/universidade está deixando de ser o único lugar da legitimação do saber, o que constitui um enorme desafio para o sistema educativo. Diante desse desafio, muitas vezes os docentes adotam uma posição defensiva e, às vezes, até negativa no que se refere às mídias e às tecnologias digitais. É preciso que, perante essa nova ordem das coisas, a escola, a universidade e seus profissionais não se afastem, mas busquem compreender o que se passa e se disponham a interagir com as novas possibilidades.

No exercício da docência, muitas pessoas são provocadas pela mobilidade física e informacional das tecnologias móveis. Primeiramente, porque querem atenção, olho no olho, e interação; por outro lado, há um dispositivo que transporta esse sujeito fixo para uma série de mundos que não o da nossa aula preparada e organizada, sem a participação desse coadjuvante. Isso quebra a rotina, desafia, por isso incomoda e causa tensões. Apesar de dispositivos eletrônicos serem usados por todos em quaisquer espaços, alguns pensam que a sala de aula, o território sagrado do saber, não pode ser alterada.

Como salienta Bonilla (2011), não é possível pensar em um currículo separado de uma das principais dimensões do sujeito, que é a sua dimensão técnica. É preciso pensar na produção e na inserção dos sujeitos no contexto tecnológico permeado de tecnologias, analógicas ou digitais, móveis ou não.

Nesse sentido, procurei conhecer as opiniões dos professores acerca da contribuição do celular para a aprendizagem do aluno do Ensino Superior. Eles assim responderam (informação verbal):

Depende do uso, eu acho que pode contribuir sim. (Prof. A).

Eu acho que contribui porque é uma ferramenta que você... às vezes você está com uma dúvida de alguma coisa, às vezes eu mesmo estou com dúvida de algum termo, de alguma expressão, no uso da língua portuguesa, aí você vai na Internet e tira a dúvida, mas... penso que as pessoas estão extrapolando um pouquinho, sabe? Mas ela é uma ferramenta fantástica nesse sentido. É, se isso for no sentido de aprendizagem, é sim... porque, quando eu tiro a dúvida, eu tô [sic] aprendendo, né? (Prof. B).

Eu sempre parto do princípio que a informação, ela é importante, mas tem um certo limite se essa informação, se ela não for aprofundada, se ela não for utilizada com outras relações, com outras fontes de informação e de conhecimento que ajude aquela informação primeira, então eu acredito e compreendo que há uma necessidade de você tomar conhecimento de determinada informação, mas aprofundá-la, relacioná-la a outros campos, de modo que a informação deixe de ser apenas informação e passe a ter um caráter de conhecimento para o aluno, de acréscimo, aprofundamento teórico prático para o aluno. (Prof. C).

Não. Acho que não. A sala de aula em si é suficiente, e os trabalhos feitos fora de sala e tal, mas eu ainda tenho resistência em celular em sala. (Prof. D).

Se ele utiliza para fins de uma pesquisa bibliográfica, se ele utiliza para a comunicação com os colegas, comunicação com o professor, sim, aí é positivo. (Prof. ${ }^{a}$ E). 
As opiniões são divergentes, mas há um consenso quanto à principal contribuição do celular: o acesso à informação para realização de pesquisas acadêmicas. O conhecimento está disponível em rede, na qual todos podem intervir de forma cooperativa, promovendo uma interação entre os sujeitos para construir um grande fluxo de informação e de produção de conhecimentos. É interessante pensar que, por muito tempo, esse também era o principal uso dos computadores com acesso à Internet nas escolas: fazer pesquisas. Penso ser um uso restrito diante de tantas possibilidades das tecnologias móveis no ensino na contemporaneidade. A constituição de redes para conexão de ideias, experiências, sujeitos e aprendizagens potencializadas com as tecnologias digitais ainda não é concebida. Além disso, nenhum dos entrevistados citou o uso do celular como apoio na realização das atividades propostas em sala de aula ou como forma de comunicação com a turma no decorrer da disciplina. Os dados não podem ser generalizados e é certo que há outras experiências com as tecnologias móveis que podem estar sendo realizadas entre os docentes, mas estas não foram citadas pelos entrevistados.

As tecnologias digitais móveis trazem consigo termos como conexão, mobilidade e acesso rápido à informação, à produção e ao compartilhamento. Diferentemente de outras tecnologias, a Internet possibilita a qualquer pessoa produzir e publicar vídeos, livros, músicas, imagens e uma infinidade de coisas. Na visão de Lemos (2010), a liberação da palavra que é própria dos processos que circunscrevem a cibercultura poderia transformar a sala de aula em um ambiente problematizador.

\begin{abstract}
Ao invés de se configurar como um espaço de poder em que os alunos se colocam na posição de meros ouvintes/leitores da autoridade cognitiva representada pelo professor e pelos livros, teríamos alunos (incluindo-se aí os professores que são alunos) capazes tanto de questionar as "leituras", quanto de atualizá-las pela escrita, assumindo o lugar de autores. Não se trata, segundo ele, de colocar as instituições de ensino na situação de refém dos equipamentos eletrônicos, mas sim de introduzir na sala de aula a lógica da cibercultura, que, baseada na liberação da palavra, possibilita aos praticantes o exercício político do diálogo (LEMOS, 2010, p. 111).
\end{abstract}

Transformar a sala de aula em um ambiente propício para a problematização a partir da liberação da palavra na rede, introduzindo-se, na sala de aula, a lógica das redes, em que todos são chamados a compartilhar sua opinião, é a proposta de Lemos (2012) e, sem dúvida, o grande desafio para escolas, universidades e educadores de todos os níveis de ensino. Compartilho com as autoras a compreensão de que "o digital tem como característica a plasticidade, o movimento, a bricolagem e, agregado ao potencial das redes, favorece relações mais horizontalizadas de produção e trocas de saberes e construção de conhecimentos (CORDEIRO; BONILLA, 2015, p. 272).

\title{
4 Desconectando por um instante
}

[...] mas é preciso compreender que nas circum-navegações da vida uma brisa amena para uns pode ser para outros uma tempestade mortal, tudo depende do calado do barco e do estado das velas (SARAMAGO, 2000, p. 114).

Busco nas palavras de Saramago o fio das ideias para encerrar esse diálogo. E diálogo na perspectiva histórico-cultural não é consenso. Cada sujeito constrói seus sentidos e significados a partir das relações e interações nas quais se constitui, e não é diferente para os docentes pesquisados e para a própria pesquisadora, que tem olhares implicados para a questão. 
Estudantes e docentes fazem parte da cultura digital e estão conectados à rede sem fio para fins variados, construindo sentidos e significados a partir do que conhecem e das vivências tecidas com as tecnologias móveis. Tais vivências adentram as salas de aulas e demais espaços da Universidade. Os sujeitos não conseguem "desgrudar" os olhos da tela do celular, ao mesmo tempo em que exercem as mais diversas atividades, exercitando ao máximo as mobilidades física, informacional e do pensamento.

A partir das entrevistas realizadas neste estudo, ficou claro que o uso do celular para consumo de informações na rede, com o intuito de fazer pesquisas, é o mais destacado pelos professores como algo significativo de se realizar com o aparelho celular em sala de aula. Sendo assim, pesquisar na Internet por meio do celular na sala de aula é uma atividade reconhecida como importante e permitida pelo consenso dos professores. No entanto, é interessante notar que exemplos de trabalhos com uso de aplicativos, produção de documentários, escritas coletivas, trabalhos com fotografias, sons, entre outros, não foram mencionados. Como sinaliza Santaella (2013, p. 27), "mergulhar no jogo das complementaridades deveria ser o mote para nós educadores em prol de formas de aprendizagem que estejam em sintonia com os sinos que tocam no nosso tempo".

"A mobilidade do pensamento, física e informacional, determina as relações de poder no momento em que ela possibilita a compreensão do mundo, e do eu no mundo" (CORDEIRO; BONILLA, 2017, p. 263). Ao circular e interagir nos diversos territórios informacionais, temse acesso à informação e à comunicação que colaboram com a construção das identidades, subjetividades, sentidos e significados.

No entanto, a mobilidade do pensamento e informacional do estudante a partir do uso do celular com conexão em sala de aula confronta-se com a necessidade do professor de ter esse estudante conectado em sua aula e não no celular. A presença/ausência do sujeito, ao estar em contato com dispositivos móveis, é uma arena carregada de problematizações em todas as esferas, não sendo diferente na sala de aula. Assim, a sala de aula se torna um palco de tensões, acordos e negociações, na tentativa de articular a ubiquidade das tecnologias móveis e suas desterritorializações/reterritorializações.

É necessário que os docentes do Ensino Superior reflitam sobre a tecnologia digital móvel como uma colaboradora/mediadora da produção do conhecimento nesse contexto, e não como um intruso, que vem para atrapalhar ou interferir em sua prática pedagógica e dispersar os estudantes. Suas narrativas denotam desconfiança, descrença e preferência por cautela com o uso, embora considerem interessante "liberar" para realização de alguma pesquisa, o que me leva a indagar: como as tecnologias móveis com conexão à internet podem, na educação, deixar de ser uma zona de tensões e transformar-se em uma zona de possibilidades para o processo ensino-aprendizagem de estudantes imersos na cultura digital?

Desse modo, a universidade, produtora de conhecimento, deveria conhecer e debater as novas formas de pensar, agir e expressar que a cultura digital provoca. São muitos os desafios a serem enfrentados pelos professores e pelos currículos dos cursos de licenciatura, diante das mudanças que já ocorreram e das que estão para ocorrer a partir dos avanços tecnológicos, que certamente influenciarão no modo de ensinar e aprender. Não se trata apenas de optar por usar ou não os instrumentos tecnológicos como um suporte, mas de levar em conta as lógicas contemporâneas que essas tecnologias e suas linguagens fazem emergir. Como os sentidos e significados são mutantes, eles podem ser ressignificados e desterritorializados a partir de novos estudos. É importante que esse debate passe a ser pauta com mais efetividade na vida formativoacadêmica das licenciaturas, pois já não se pode alijá-lo das relações de ensino, pesquisa e extensão, funções básicas da universidade na difusão e na criação do conhecimento. 


\section{Referências}

BAKHTIN, Mikhail. Estética da criação verbal. Trad. Paulo Bezerra. 4. ed. São Paulo: Martins Fontes, 2003.

BONILLA, Maria Helena Silveira. Formação de professores em tempos de WEB 2.0. In: FREITAS, Maria Teresa de Assunção (org.). Escola, Tecnologias Digitais e Cinema. Juiz de Fora: Ed. UFJF, 2011.

COSTA, Rogério. A cultura digital. 3. ed. São Paulo: Publifolha, 2008.

CORDEIRO, Salete de Fátima Noro; BONILLA, Maria Helena Silveira. Tecnologias digitais móveis: reterritorialização dos cotidianos escolares. Educar em Revista, n. 56. Curitiba, Editora UFPR, abr./jun., 2015, p. 259-275.

CORDEIRO, Salete de Fátima Noro; BONILLA, Maria Helena Silveira. Cotidianos escolares e tecnologias digitais móveis: relações, tensões e ressignificações. In: $\mathbf{3 8}^{\mathbf{a}}$ Reunião Nacional da ANPEd - 01 a 05 de outubro de 2017 - UFMA - São Luís/MA.

FREITAS, Maria Teresa de Assunção. A abordagem sócio-histórica como orientadora da pesquisa qualitativa. Cadernos de Pesquisa, n. 116, p. 21-39, jul., 2002.

FREITAS, Maria Teresa de Assunção. A perspectiva sócio-histórica: uma visão humana da construção do conhecimento. In: FREITAS, Maria Teresa Assunção; JOBIM e SOUZA, Solange; KRAMER, Sônia (Orgs.). Ciências humanas e pesquisa: leituras de Mikhail Bakhtin. São Paulo: Cortez, 2003.

LEFFA, Vilson. Vygotsky e o ciborgue. In: SCHETTINI, Rosemary Hohlenwerger [et al.]. Vygotsky: uma revisita no início do século XXI. São Paulo: Andross, 2009.

LEMOS, André. Cibercultura e Mobilidade. A Era da Conexão. In: XXVIII Congresso Brasileiro de Ciências da Comunicação - UERJ - 5 a 9 de setembro de 2005.

LEMOS, André. Ciberespaço e tecnologias móveis: processos de territorialização e desterritorialização na cibercultura. In: MÉDOLA, Ana Silva.; ARAÚJO, Denise Correia; BRUNO, Fernanda. (org.). Imagem, visibilidade e cultura midiática. Porto Alegre: Sulina, 2008. p. 277-293.

LEMOS, André. Cultura da mobilidade. Revista FAMECOS, n. 40, Porto Alegre, dez., 2009.

LEMOS, André. Celulares, funções pós-midiáticas, cidade e mobilidade. Revista Brasileira de Gestão Urbana, [S.1.], v. 2, n. 2, p. 155-166, jul./dez. 2010. ISSN 2175-3369. Disponível em: <https://periodicos.pucpr.br/index.php/Urbe/article/view/5344/20871〉. Acesso em: 25 out. 2018 .

LEMOS, André. Cibercultura como território recombinante. In: TRIVINHO, E.;

CAZELOTO, E. (org.). A cibercultura e seu espelho [recurso eletrônico]: campo de 
conhecimento emergente na nova vivência humana na era da imersão interativa. São Paulo: Instituto Itaú Cultural, 2009, p. 38-46. Disponível em:

<http://abciber.org/publicacoes/livro1/a_cibercultura_e_seu_espelho.pdf >. Acesso em: 20 nov. 2017.

LEMOS, André; LÉVY, Pierre. O futuro da internet: em direção a uma ciberdemocracia planetária. São Paulo: Paulus, 2010.

LÉVY, Pierre. Cibercultura. Trad. Carlos Irineu da Costa. São Paulo: Ed. 34, 1999.

MARTÍN-BARBERO, J. Tecnicidades, identidades, alteridades: mudanças e opacidades da comunicação no novo século. In: MORAES, Dênis. Sociedade midiatizada. Rio de Janeiro: Mauad X, p. 51-79, 2006.

SARAMAGO, José. A Caverna. São Paulo: Companhia das Letras, 2000.

SANTAELLA, Lúcia. Linguagens Líquidas na era da mobilidade. São Paulo: Paulus, 2007.

SANTAELLA, Lúcia. Desafios da Ubiquidade para educação. Ensino Superior Unicamp. 2013. Disponível em: <https://www.revistaensinosuperior.gr.unicamp.br/artigos/desafiosdaubiquidade-para-a-educacao>. Acesso em 15 out. 2019.

SILVA, Ana Elisa Drummond Celestino Silva; COUTO, Edvaldo Souza. Professores usam smartphones: considerações sobre tecnologias móveis em práticas docentes. In: $\mathbf{3 6}^{\mathbf{a}}$ Reunião Nacional da ANPEd - Goiânia-GO - 29 de setembro a 02 de outubro de 2013.

SILVA, Maria da Graça Moreira. Mobilidade e construção do currículo na cultura digital. In: ALMEIDA, Maria Elizabeth Bianconcini de; DIAS, Paulo; SILVA, Bento Duarte (org.). Cenários de inovação para a educação na sociedade digital. São Paulo: Edições Loyola, 2013.

VYGOTSKY, Lev Semenovich. Génesis de las funciones psíquicas superiores. In:

VYGOTSKY, Lev Semenovich. Obras escogidas. III Madrid: Visor, 1995.

VYGOTSKY, Lev Semenovich. A construção do pensamento e da linguagem. Trad. Paulo Bezerra. São Paulo: Martins Fontes, 2001.

VYGOTSKY, Lev Semenovich. A Formação Social da Mente: o desenvolvimento dos processos superiores. 7. ed. São Paulo: Martins Fontes, 2007. 